\title{
Effect of Large Compress Aroma Lavender Therapy to Intensity Scale and Old Labor of I there are Active Phase Until Second Stage in Primigravida Mother in the Region Puskesmas Pagak District Malang
}

\author{
Widiastuti ${ }^{1}$, \\ Yuly Peristiowati ${ }^{2}$, \\ Siti Farida ${ }^{2}$ \\ ${ }^{1}$ Magister of Health Study \\ Program of STIKes Surya Mitra \\ Husada Kediri \\ ${ }^{2}$ Lecturer of STIKes Surya Mitra \\ Husada Kediri \\ Email: \\ widi2009astuti@gmail.com
}

Received: October 4, 2018

Accepted : October 6, 2018

Published : November 30, 2018

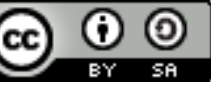

\begin{abstract}
The pain of labor may potentially activate the sympathetic nervous system that inhibits endogenous oxytocin secretion, which can be resolved by the method of using warm compress therapeutic aromatherapy lavender to make vasodilatation of blood vessels so that the hormone oxytocin in the body more optimal and will help the contraction of the smooth muscle of the uterus that affect the labor so that run faster.Penelitian aims to determine the influence of warm compresses of lavender aromatherapy on pain intensity and duration of labor in active phase until premiere of second stage labor on primigavida maternity. The research design is True Experimental Design. Population of primigravida pregnant women who have interpretation of birth November-December 2017 in Pagak Puskesmas region consisting 42 respondents. The sampling technique using Simple Randomization was obtained 38 respondents (control and treatment group). Intensity was measured using VAS (Visual Analogue Scale) scale and the length of labor was measured by partograph (minutes). The result of calculation of Hotelling T2 (sig 0,05) 62,8392.> 6,7216. H0 is rejected, meaning that there is a difference between the mean on the control and the average on the treatment. The use of warm compresses of lavender aromatherapy decreased the intensity of labor pain by $30.8 \%$, while for the duration of labor acceleration occurred $26.4 \%$. Thus warm compresses of lavender aromatherapy as one of the interventions in reducing the intensity of pain and labor acceleration in primigravid maternity, and can be applied to various health services.
\end{abstract}

Keywords: Warm compress, length of delivery, lavender, pain Copyright @ 2018 STIKes Surya Mitra Husada All right reserved.

This is an open-acces article distributed under the terms of the Creative Commons Attribution-ShareAlike 4.0 International License.

\section{INTRODUCTION}

Labor pain is an unpleasant feeling due to excitation of special nerve endings, this pain is due to uterine contractions, cervical dilatation and perineal distention carrying visceral afferent nerve fibers carrying the sensory impulses from the uterus entering the spinal cord in T segments 10-12 and S2, S3 , S4 (Marmi, 2012).

The old Partus is one of the few causes of maternal and neonatal death. According to data from the Directorate of Maternal Health (2013) is According to data from the Indonesian Demographic and Health Survey, the old partus in 2010 reached 1.0\%, in 2010 reached $1.1 \%$, in 2013 up 1.8\%. At Pagak District Health Center of Malang Regency (2016) the number of incidence of the first time is 13 maternal mothers, while the second stage of the old as many as 5 mothers and based on 
preliminary study in September 2017 in the work area Pagak Puskesmas at 10 mothers feel pain during childbirth.

This study aims to study the effect of warm aromatherapy lavender compress on intensity of pain scale and duration of labor in active phase of second stage of labor on primigavida maternity.

Labor pain may potentially activate the sympathetic nervous system that would inhibit the maternal endogenous oxytocin secretion. Birth pain can be overcome by non-pharmacological method, that is using warm compress therapy aromatherapy lavender make vasodilatasi restorative blood so improve blood circulation in network hence oxytocin hormone work in the body more optimal and will help contraction of smooth muscle of uterus which influence delivery passable faster.

Overcoming labor pain is divided into two methods that can be applied namely: pharmacological methods (using drugs) and non-pharmacological methods (Mayurnani, 2010). The non-pharmacological method effectively overcomes the pain and has no impact on the baby to be born. The alternative methods of pain relief include: modulation of psychological pain (relaxation, hypnotherapy, imagination, biological feedback, psychoprofilaxis) and sensory modulation of pain (massage, therapeutic touch, cold hot compress, acupressure, acupuncture, TENS, distraction with music, hydrotherapy, , posture and ambulation, shout) (Mander, 2006). The purpose of this study was to determine the effect of warm compress of lavender aromatherapy on pain intensity and duration of labor in active phase to second stage labor on primigavida maternity.

First stage labor pain may occur due to the appearance of uterine contractions, cervical stretching at opening time, uterine ischemia (decreased blood flow to local oxytocin deficit) due to myometrial artery contraction. The discomfort of cervical changes and uterine ischemia is visceral (sympathetic) pain located beneath the abdomen that spreads the lumbar spine of the back and decreases to the thigh, ie in T10-T12 (Norwitz, Errol, and Schorge, 2006).

According to Manuaba (2012) at the second cervical labor stage of full dilation (opening of $10 \mathrm{~cm}$ ), the ongoing pain stimulation of uterine contractions and lower uterine segment distension and progressively increased pressure by the fetus on the pelvic structure leads to increased somatic pain, with strain and tear of the fascia and subcutaneous tissues of the lower birth canal, perineal distention and pressure on the perineum lurik muscle. Pain is transmitted through the pudendal nerve fibers of somatic nerve fibers and exits through S2, S3 and S4 sacral segments and the intensity felt is intense and the location is clear. The characteristics of uterine contractions increase in the phase of labor when the second stage of frequency Each 1.5-2 minutes, the duration of 80-90 seconds with the intensity when the intrauterine pressure is $70-90 \mathrm{mmHg}$.

According to Judha et al (2012), factors affecting labor pain are: race, culture, emotions (anxiety and fear), personality, experience of labor support system, labor preparation, coping mechanisms, relaxation methods used, fatigue, hope. The duration of labor Kala I s.d second stage. According to Prawirohardjo (2009), it is explained that the time duration of the active phase is 4.6 hours, cervical opening at active phase $4-10 \mathrm{~cm}$ and second stage up to 3 hours. In the early primigravida labor I stage lasted about 13-14 hours. While for multipara lasted 6-7 hours (Prawirohardjo, 2009). Kala II is also called expenditure, this time starting from the complete opening (opening $10 \mathrm{~cm}$ ) until the baby is born. This process lasted 2 hours on Primipara (Sumarah, 2009).

\section{RESEARCH METHODS}

Design in this research is True Experimental Design. All Primigravida pregnant women who had labor interpretation November-December 2017 in Pagak Puskesmas area of 42 people, who fulfilled low risk requirement based on Poedji Rohcjati score, screening of labor and not contraindication of warm compress aroma of lavender therapy which amounted to 42 respondents. Sampling technique using Simple Randomization got 38 respondents, consisting of group of 19 respondent of control group and 19 respondent of treatment group.

Providing warm lavender aromatherapy compresses lavender aromatherapy oil with $25 \mathrm{ml} /$ $0.84 \mathrm{fl} \mathrm{oz}$ in $200 \mathrm{cc}$ water added with $15-40^{\circ} \mathrm{C}$ temperature, using a clean and dry towel dipped into the solution at the back area of the primigravida maternity mother who has contraindication or hypersensitivity of giving compress warm lavender aromatherapy and no fetal or maternal discharge occurs. The given dosage is $0.3 \mathrm{cc}$ of lavender aromatherapy oil for 2 hours once during labor I to the second stage of labor. The level of pain was measured using a VAS scale (Visual Analogue Scale) 
and the length of labor was measured by partographs in minutes and then the results were tested with two independent sample T-Tests and Hotteling T test.

\section{RESEARCH RESULT}

Based on the research results obtained general data as follows:

Table 1.1 General Data Distribution of respondents based on Pagak Puskesmas working area November of 2017 - January 2018

\begin{tabular}{|c|c|c|c|}
\hline \multicolumn{2}{|c|}{ Variabel } & Treatment & Control \\
\hline Age & Average & $22 \pm 0,64$ & $23 \pm 0,86$ \\
\hline \multirow{3}{*}{ Education } & Primary School & $15,8 \%$ & $21,0 \%$ \\
\hline & Junior High School & $57,9 \%$ & $57,9 \%$ \\
\hline & Senior High School & $26,3 \%$ & $21,0 \%$ \\
\hline \multirow{2}{*}{ Work } & Work & $10,5 \%$ & $15,8 \%$ \\
\hline & unemplyoiment & $89,5 \%$ & $84,2 \%$ \\
\hline
\end{tabular}

From the general data, the mean age in the treatment group was $22 \pm 0.64$ tajun and in the control group was $23 \pm 0.86$. Most respondent's education is junior high school and most of respondent is not working earn a living.

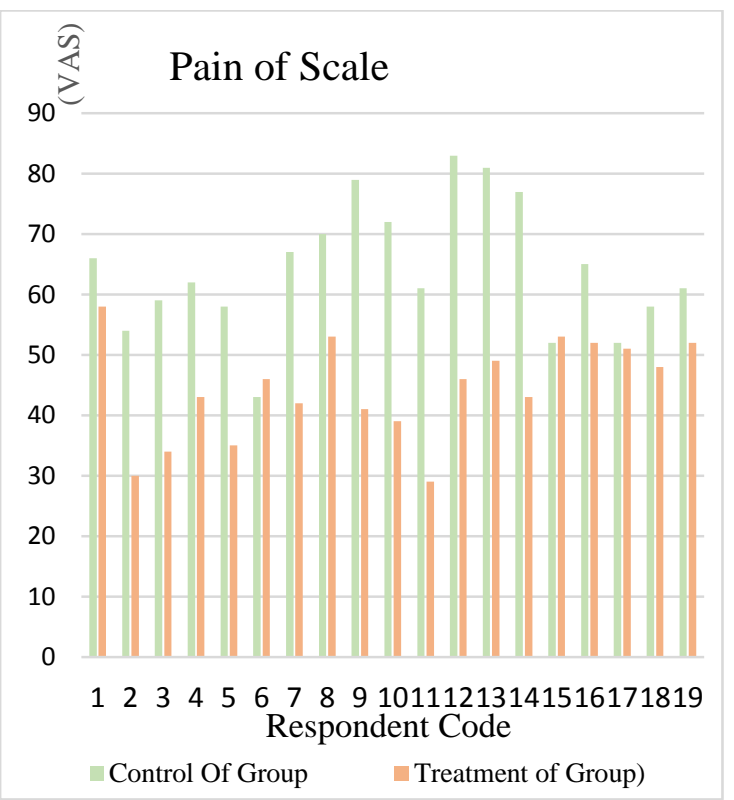

Figure 1.1 Differences in the intensity of respondent pain in the working area of Pagak Puskesmas November 2017 - January 2018

In picture 1.1 there are 16 respondents experiencing differences in the intensity of labor pain, there are 2 respondents who did not experience penurunn intensity of pain. 


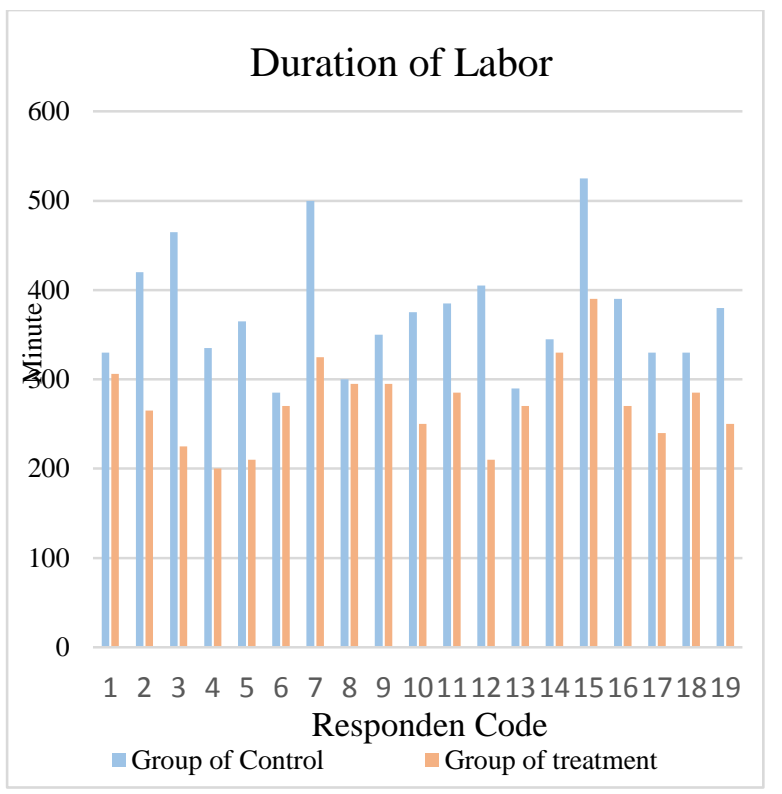

Figure 1.2 Differences in the duration of births of respondents in the working area of Pagak Puskesmas November 2017 - January 2018.

In Figure 1.2 also explains that all deliveries with warm compresses of lavender aromaterpigy overall have accelerated labor.

Table 1.2 Compress Analysis Warm aromatherapy of lavender on the intensity of pain and duration of birth of respondents in Pagak Puskesmas working area November of 2017 - January 2018.

\begin{tabular}{|c|c|c|c|}
\hline \multicolumn{2}{|r|}{ Variabel } & Perlakuan & Kontrol \\
\hline \multirow{3}{*}{ Pain intencity (VAS) } & Rerata & $44,42 \pm 10,81$ & $64,21 \pm 8,24$ \\
\hline & $\mathrm{t}$ test 2 sample independent with $\alpha(\operatorname{sig}<0,05)$ & \multicolumn{2}{|c|}{0.000} \\
\hline & Rerata & $275,26 \pm 51,1$ & $373,95 \pm 66,5$ \\
\hline $\begin{array}{l}\text { Duration of labour } \\
\quad \text { (minute) }\end{array}$ & $\mathrm{t}$ test 2 sample independent with $\alpha(\operatorname{sig}<0,05)$ & \multicolumn{2}{|c|}{0,000} \\
\hline & ${\text { Hotelling } \mathrm{T}^{2}}^{2}$ & \multicolumn{2}{|c|}{62,8392} \\
\hline & $\alpha(\operatorname{sig}<0,05)$ & \multicolumn{2}{|c|}{6,7216} \\
\hline
\end{tabular}

The results showed the pain intensity in the control group $64.21 \pm 8.24$ treatment was decreased VAS scale of $44.42 \pm 10.81$ and duration of labor in the control group $373.95 \pm 66.5$ occurred acceleration in the treatment group $275.26 \pm 51.1$. The calculation result of Hotelling $\mathrm{T}^{2}$ (sig $0.05) 62,8392 .>6,7216$ test.

\section{DISCUSSION}

Providing a warm compress of lavender aromatherapy can reduce the intensity of pain and accelerate labor of primigravida when I phase is active until Kala II.

The warm compress of lavender aromatherapy has the effect of vasodilation of blood vessels thus improving blood circulation in the tissues so the oxytocin hormone work in the body is more optimal and will help the contractions of smooth uterine muscles affecting childbirth can be passed more quickly (Andarmoyo, 2016).

Effects of intermittent and cold local heat on labor pain and childbirth outcomes The pain was significantly lower in the intervention group during the first and second phase of labor. The duration of the first stage and the third phase of labor is shorter in the case group. There was no difference in 
the type of labor, perineal laceration, oxytocin uptake, fetal heart rate, and APGAR between the two groups (Ganji, Zhila, Shirvani, 2013).

Intensity of pain and duration of labor are influenced by several factors: respondent's age, respondent's education, respondent's job, passanger (weight, body length, and baby's head circumference), labor companion and episiotomy.

\section{CONCLUSIONS AND RECOMMENDATIONS}

\section{Conclusion}

Therapy of warm compress Aromatherapy lavender with $25 \mathrm{ml} / 0.84 \mathrm{fl} \mathrm{oz}$ in the back area with doses of $0.3 \mathrm{cc} / 2 \mathrm{~h}$ during labor from stage I to stage II of delivery as one of intervention in decreasing pain intensity $30,8 \%$ and speeding labor , $4 \%$. In maternal mothers.

\section{Suggestion}

It is necessary to conduct similar research with larger sample to get better result accuracy. In the subsequent research, all variables affecting 5P (Power, Pasage, Pasenger, Psychic, and Rescue), internal factors (experience, knowledge of pain, age, physical activity) and external factors (Religion, physical environment, culture, support system, socio-economic).

Variables for similar research can be extended beyond the influence of warm compresses of lavender aromatherapy, but also include other factors related to the success of birth care, such as reducing pain and accelerating labor in the first stage of phase I, III or Kala IV or puerperal phase and not only in primigravid mom but also to the mother.

\section{BIBLIOGRAPHY}

Andarmoyo, S. \& Suhartati. (2014). Persalinan Tanpa Nyeri Berlebihan. Jogjakarta: Ar-Ruzz Media.

Ganji, Zhila, Shirvani, dkk. (2013). 'The Effect of Intermitten Local Heat and Cold on Labour and Child Birth Outcome', Mazadran Univeristy of Medical Science, pp. 298-303.

Judha, Mohamad. Sudarti, \& F. (2012). Teori Pengukuran dan Nyeri Persalinan. Jogjakarta: Nuha Medika.

Mander, R. (2006). Nyeri Persalinan. Jakarta: EGC.

Manuaba, F. M. (2012). Pengantar Kuliah Obstetri. Jakarta: EGC.

Manuaba, F. M. (2012). Ilmu Kebidanan, Penyakit Kandungan, dan KB untuk Pendidikan Bidan Edisi 2. Jakarta: EGC.

Mayurnani, A. (2010). Nyeri dalam Persalinan, Teknik, dan Cara Penanganannya. Jakarta Timur: CV Trans Info Media.

Norwitz, Errol, \& Schorge, J. (2006). At Glance Obstetri dan Ginekologi Edisi Kedua. Jakarta: Erlangga.

Prawirohardjo, S. (2009). Pelayanan Kesehatan Maternal dan Neonatal. Jakarta: PT Bina Pustaka.

Poedji, Rochjati. (2003). Skrining Antenatal pada Ibu Hamil. Surabaya: Fakultas Kedokteran UNAIR.

Sumarah. (2009). Asuhan Kebidanan pada Ibu Bersalin. Jakarta: Fitramaya.

Sumarah. (2009). Midwifery Care in Maternity Mother. Jakarta: Fitramaya. 